\title{
Potent Effect of Superoxide Dismutase -Like Activity of Partially Purified Protein from Raphnus Sativus Roots on Transforming Growth Factor and Vascular Endothelial Growth Factor In Ehrlich Ascites Carcinoma Bearing Mice
}

\author{
Salem A. Habib ${ }^{1 *}$, Laila A. Eissa ${ }^{2}$, Mohammed M. Abdel Latif \\ ${ }^{1 *}{ }^{3}$ Chemistry Department (Biochemistry Division), Faculty of \\ Science, Damietta University, New Damietta, Egypt ${ }^{2}$ Biochemistry \\ Department, Faculty of Pharmacy, Mansoura University, Egypt
}

\begin{abstract}
The alterations in cancer cell's metabolism have been associated with enhanced oxidative stress. Therefore, a partially purified SOD-like activity protein from the roots of Raphnus sativus ( $R$. sativus) and low-molecular-weight heparin (LMWH) were tested for their abilities to inhibit the growth of Ehrlich ascites carcinoma cells (EAC) intraperitoneally implanted in albino mice. Ninty mice were randomly divided into 6 groups. The antitumor effect of the partially purified protein and LMWH were assessed by estimating transforming growth factor Beta (TGF- $\beta$ ) and vascular endothelial growth factor (VEGF) in serum. Also, tumor volume, median survival time (MST), total lipids, DNA and RNA contents in liver tissues as well as liver function tests and the redox status were estimated. TGF- $\beta, V E G F, D N A, R N A$, and malondialdehyde (MDA) levels in addition to serum alanine transaminase (ALT) and gamma glutamyl transferase (GGT) activities and tumor volume were highly significantly increased $(P<0.001)$ in the untreated EAC-bearing mice compared to those of the control. However, total lipids in liver tissues and serum albumin were highly significantly decreased in the same group compared to the corresponding values of the control group. All these parameters were restored to their normal levels in the partially purified extract and LMWH treated EAC-bearing mice groups compared to the untreated EAC-bearing mice. It could be concluded that, the partial purified protein with SOD-like activity from the roots of $R$. sativus and the LMWH have a remarkable anti-tumor activity against EAC cells in Swiss albino mice through its potent effect on both TGF- $\beta$ and VEGF.

Keywords Transforming growth factor- $\beta$; vascular endothelial growth Factor; Ehrlich Ascites carcinoma (EAC); Low-molecular-weight heparins; Raphnus sativus; and SOD-like activity
\end{abstract}

\section{INTRODUCTION}

Reactive oxygen species (ROS), such as hydrogen peroxide $\left(\mathrm{H}_{2} \mathrm{O}_{2}\right)$, superoxide radical, hydroxyl radical, and singlet oxygen, are implicated in the pathogenesis of a number of diseases, including atherosclerosis, cancer, Alzheimer's disease, acute liver failure, and hepatic fibrosis ${ }^{[1]}$. ROS is well recognized for playing a 
dual role; they can be either harmful or beneficial to living systems [2]. Beneficial effects of ROS occur at low/moderate concentrations in defense against infectious agents in the function of a number of cellular signaling systems and in the induction of a mutagenic response.

In recent years, evidence has accumulated for a role of reactive oxygen metabolites as a mediator of tissue injury in several animal models ${ }^{[3-4]}$. Although, the exact mechanisms of free-radical generation are not yet completely understood, it is postulated that the antioxidant GSH depletion by the intestinal parasites may be a trigger for the production of reactive oxygen species (ROS) ${ }^{[5]}$. Generation of ROS in the cytoplasm of cells may increase the mitochondrial hydrogen peroxide production and lipid peroxidation of cell and mitochondrial membranes, resulting in loss of membrane integrity and finally cell necrosis or apoptosis ${ }^{[6]}$. Excessive endogenous ROS levels result in oxidative damage that has been implicated as the cause of various human and experimental pathological processes, including chronic inflammation, tissue aging, and cancer.

Oxidative stress is caused by an imbalance between the production of reactive oxygen and a biological system's ability to readily detoxify the reactive intermediates or easily repair the resulting damage. Oxidative damage to DNA strands followed by mutation and alterations in gene expression are the principal mechanisms by which ROS contribute to carcinogenesis ${ }^{[7]}$. Therefore, protective and beneficial roles of superoxide dismutase (SOD) have been demonstrated both pre-clinically and clinically in combating a broad range of diseases, including ischemicreperfusion injury, inflammation, and cancer ${ }^{[8]}$. Cells are normally able to defend themselves against ROS damage through the use of enzymes such as SODs and catalase. The SODs are found in prokaryotes and eukaryotes, where they catalyze the disproportionation of the superoxide radical anion $\left(\mathrm{O}_{2}^{-}\right)$in cellular processes detoxifying reactive oxygen species ${ }^{[9]}$.

SOD, an enzyme that catalyses the degradation of $\mathrm{O}_{2}^{-}$to oxygen and hydrogen peroxide, was discovered approximately 40 years ago. SOD was presumably the most potent anti-ROS and was initially thought to be potentially a dream drug. In humans three SOD enzymes exist, SOD1 is a cytoplasmic $\mathrm{Cu} / \mathrm{Zn}-\mathrm{SOD}, \mathrm{SOD} 2$ is a mitochondrial Mn SOD and SOD3 is an extracellular $\mathrm{Cu} / \mathrm{Zn}$ SOD. Many studies report the purification of Mn SOD from animal blood and plants like watermelon, pea, garlic and pearl millet ${ }^{[\mathbf{1 0 ]}}$. The tumor cells were inhibited by the addition of these exogenous isolated Mn-SODs [10]. Manganese superoxide dismutase (Mn-SOD) is one of the major enzymes responsible for the defense against oxidative damage due to ROS in the mitochondria ${ }^{[11]}$.

Raphnus sativus ( $R$. sativus) is an annual herb, consumed as vegetable. It belongs to the family Brassicaceae. It has been used in folk medicine as a natural drug against many toxicants. It decreases blood glucose levels in diabetic rats ${ }^{[12]}$ and improves the histopathology of colon mucosa in the 
rats fed high fat diet ${ }^{[13]}$. Recently, Habib and Othman reported that SOD from $R$. sativa up-regulate erythrocytes glucose uptake in diabetic patients ${ }^{[\mathbf{1 4}]}$. Radish extract improves the antioxidant status of male mice and can overcome or, at least, significantly diminish mycotoxin (Zearalenone) effects ${ }^{[15]}$.

Heparin and low molecular weight heparin (LMWH) are commonly used for the prevention or treatment of thromboembolic complications in cancer patients ${ }^{[\mathbf{1 6}]}$. Based on earlier observations linking the anticoagulant therapy with heparin to an improved survival of cancer patients, several prospective clinical trials were launched with the aim to test heparin as a potential anticancer treatment ${ }^{[17]}$. Preclinical analysis of heparin provides evidence for its antimetastatic activity in a variety of animal models ${ }^{[18]}$. Heparin is a member of a class of acidic polysaccharides called glycosaminoglycans and consists of alternating residues of uronic acid and hexosamine covalently bound to serine residues of the serglycin core protein ${ }^{[19]}$.

In addition, tumor inhibition by different low molecular weight heparins (LMWH) has also been studied $^{[20]}$. Experimental evidence from various animal models consistently supports the ability of heparin to attenuate metastasis. Moreover, that protective effect was not the result of an inhibition of the growth of primary tumors, but rather the prevention of the spreading of cancer through metastases.

Therefore, the goal of that research was to study the anti-cancer and anti- metastasis effect of the SOD-like activity enzyme (natural protein partially purified from $R$. sativa) compared with low molecular weight heparin (Fraxiparine, MW $4.5 \mathrm{kDa}$ ) on EAC-bearing mice.

\section{MATERIALS \& METHODS}

Preparation of $\boldsymbol{R}$. sativus extract:

About $400 \mathrm{~g}$ of root tissues of $R$. sativus were homogenized with one liter ice-cold tris buffer $\mathrm{pH}$ 7. The resulted supernatant was precipitated with $80 \%$ ammonium sulfate and the precipitated protein was passed through calcium phosphate gel, which then eluted with serial concentrations of $\mathrm{NaCl}$ solutions. The protein after elution with 0.4 and $0.8 \mathrm{M}$ saline solution was dialyzed against distilled water and then concentrated using polyethylene glycol. The concentrated partially purified enzyme was reconstituted with Tris buffer and applied onto sephadex $\mathrm{G}_{\mathbf{1 0 0}}$ column. The purified protein concentration and its SOD activity were assayed according the methods of Lowry et al [21] and DeChatelet et al., [22] respectively.

Sodium Dodecyl Sulfate Polyacrylamide Gel Electrophoresis (SDS-PAGE) of the purified enzyme:

Protein sample was mixed with $20 \mu 1$ of SDS-PAGE loading buffer (250mM Tris- $\mathrm{HCl}, 10 \%$ SDS, $0.5 \%$ bromophenol blue, $50 \%$ glycerol $\mathrm{pH}$ 6.8 ), and incubated at $100^{\circ} \mathrm{C}$ for 5 minutes. The samples were loaded on a $10 \%$ SDS-PAG. The gel was stained with Coomassie blue and inspected visually for protein bands $^{[23]}$. 
Animals and tumor cell line:

All experiments were performed on adult female Swiss albino mice purchased from Theodore Bilharz Research Institute, Giza, Egypt, with an average body weight of 25 to $30 \mathrm{~g}$. Mice were housed in steel mesh cages (10mice/cage) and maintained for two weeks acclimatization period on commercial standard diet and tap water. The mice were randomly divided into 6 groups (15 animals each), according to the following scheme: Group I: Normal mice saline-treated group (control): Each mouse was intraperitoneally injected with daily $200 \mu \mathrm{l}$ of the physiological saline solution for 10 days. Group II: Normal mice-treated with the purified SOD: Healthy mouse treated intraperitoneally for ten days with a daily dose of $200 \mu \mathrm{l}$ purified protein (4 $\mathrm{mg} / \mathrm{Kg} \mathrm{BW} /$ day). Group III: Normal mice-treated with low molecular weight heparin (LMWH): Healthy mouse treated intraperitoneally for ten days with a daily dose of LMWH (fraxiparine) (1000 IU/Kg /BW/day) in $200 \mu \mathrm{l}$. Group IV: EAC-bearing mice saline treated: Each mouse was intraperitoneally injected once with $1 \times 10^{6}$ tumor cells. After 24 hours of tumor inoculation, the mouse was intraperitoneally injected with daily $200 \mu \mathrm{l}$ of the physiological saline solution for 10 days. Group V: EACbearing mice treated with the purified SOD: Each mouse inoculated intraperitoneally with $1 \mathrm{x}$ $10^{6}$ tumors cells, after 24 hours treated intraperitoneally for 10 days with a daily dose of $(200 \mu \mathrm{l})$ purified protein (4mg/Kg BW/day). Group VI: EACbearing mice treated with low molecular weight heparin: Each mouse inoculated intraperitoneally with $1 \times 10^{6}$ tumors cells, after 24 hours treated intraperitoneally for 10 days with a daily dose of LMWH (fraxiparine) (1000 IU/Kg /BW/day). Samples:

One day after the last treatment, ten mice of each group were sacrificed $\&$ the other 5 mice of each group remain for determination of the median survival time. The ascetic fluids containing EAC cells were collected and their volumes were measured. Liver samples were quickly dissected, rinsed with isotonic saline and dried. $0.25 \mathrm{~g}$ of these tissues was homogenized in ice cooled saline and diluted to yield a $5 \%(\mathrm{w} / \mathrm{v})$. The supernatants were used for biochemical analysis. Blood samples were also collected by cardiac puncture from deeply ether anaesthetized mice and their sera were used for subsequent analysis.

SOD-like activities of the purified enzyme:

SOD-like activities of the different concentrations of the purified protein were assayed by the method of DeChatelet et al ${ }^{[22]}$.

EAC cells cytotoxicity in vitro:

The cytotoxicity was determined using trypan blue exclusion by the method of Maclimans et al ${ }^{[24]}$. After treatment with the purified protein and the LMWH, $0.2 \mathrm{ml}$ of $0.32 \%$ trypan blue was mixed with $0.2 \mathrm{ml}$ of EAC cells and incubated for 10 minutes at $37^{\circ} \mathrm{C}$. The number of viable tumor cells, unstained cells, was counted within 5 minutes after incubation using a hemocytometer. 
Determination of median survival time (MST) and increase in life span (ILS \%):

The mortality was monitored by recording percentage increase in life span and median survival time by the method of Gupta et al ${ }^{[25]}$.

\section{Biochemical tests:}

Nucleic acids were extracted from liver homogenate by the method of Schneider ${ }^{[26]}, \mathrm{DNA}^{(27)}$ and RNA ${ }^{(28)}$ contents were determined colorimetrically in the extract. Total lipids in liver tissues homogenate were determined by the method of Knight et al. ${ }^{[29]}$. In serum activities of ALT ${ }^{(30)}$, alkaline phosphatase (ALP) ${ }^{(31)}$, GGT ${ }^{(32)}$, SOD ${ }^{(22)}$, Nitric oxide ${ }^{(33)}$ and levels of albumin ${ }^{(34)}$. Blood $\mathrm{MDA}^{(35)}$ and erythrocyte reduced glutathione ${ }^{[36]}$ (GSH) levels were also determined. TGF- $\beta$ was assayed using a commercially available assay ELISA kit (Sigma Aldrich, USA). VEGF was assayed using a commercially available assay ELISA kit (Sigma Aldrich, USA) following manufacturer's guidelines.

\section{Statistical analysis:}

The statistical analyses of the results were carried out using Instate software computer program, version 2.03 (Graph pad, USA). The one tailed P- values tables were used for statistical analysis. A difference was said to be significant, and highly significant, when the corresponding level of probability (P) was $\leq 0.05$ and $\leq 0.005$, respectively. Correlation coefficient (r) was used for measuring the relationship between two variables. The correlation is weak at $r$ $=0.50$, moderate at $\mathrm{r}=0.50-0.75$ and strong at $\mathrm{r}=0.80-1.00$.

\section{RESULTS}

$R$. sativa extract shows a protein concentration of $52.5 \mathrm{mg} / 100 \mathrm{ml}$ extract, several protein fractions are seen in the electropherogram of $\mathrm{R}$. sativa extract and an expected $\mathrm{Mn}$ SOD enzyme with a molecular mass of $25 \mathrm{kDa}$ was detected as shown in Figure 1.

The in vitro study reveals that the partial purified protein has SOD-like activity and its activity increased with increasing the concentration and reached $98 \%$ at $200 \mu \mathrm{l}$ of the extract solution. Also, the cytotoxicity of that protein and LMWH on viable EAC cells is tested The percentages of dead cells increased with increasing the concentration of the enzyme and LMWH and reached $99 \%$ and $86 \%$ respectively (Table 1).

DNA and RNA contents in liver tissues of untreated EAC-bearing mice (group IV) are highly significantly elevated compared to the corresponding control (group I). However, the levels of total lipids are highly significantly decreased in liver tissues of the same group compared to those of the control. These parameters restored their normal levels after treatment with the partial purified SOD like activity protein and LMWH (groups V and VI) (Table 2). In Table 3, SOD activity in serum of the treated mice (groups V and VI) is highly significantly increased than normal and tumorized untreated groups (I, II, III and IV). However, the levels of nitric oxide (NO) in sera and MDA in RBCs of untreated EAC-bearing (group IV) are highly significant increased, however erythrocytes GSH content is significantly decreased than 
the corresponding controls. These parameters maintained its normal values when treated with the SOD extract and LMWH (groups $\mathrm{V}$ and VI).

In untreated EAC-bearing mice (group IV), the total ascetic volume and serum levels of TGF- $\beta$ and VEGF are highly significantly elevated compared to those of the controls. These values return to the normal levels after treatment with SOD extract and LMWH (groups V and VI) (Table 4).

Table 5 shows that the serum albumin level is decreased in untreated EAC-bearing mice compared to that of the control. However, the activities of $\gamma$-GT, ALP and ALT in serum of that group are much elevated than that of the controls. The activities of $\gamma$-GT, ALP and ALT remained within normal value after treatment with SOD extract and LMWH (groups $\mathrm{V}$ and VI). In untreated EAC-bearing mice, the median survival time (MST) was $12.25 \pm 2.5$ days, while, the median survival time of EAC-bearing mice treated with the purified enzyme and LMWH were $19.00 \pm 4.69$ and $15.75 \pm 4.11$ days and the increase in life span percent were $155.1 \%$ and 128.6\% respectively (Table 6). Table (7) shows the different correlations between the different parameters in all groups.

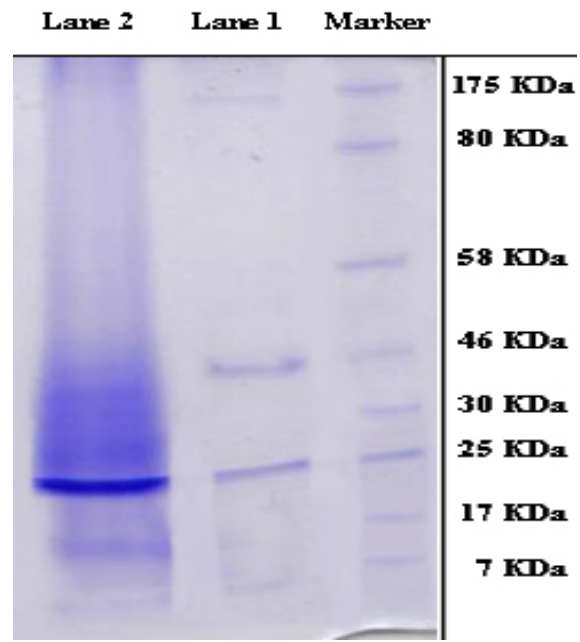

Fig. 1: SDS-PAGE for the Raphnus sativa extract (lane 1) and prestained broad range protein marker (marker) and standard SOD-enzyme (lane 2). 
Table 1: Superoxide dismutase (SOD)-like activities and cytotoxicity of the partial purified protein $(52.2 \mu \mathrm{g}$ protein $/ 100 \mu \mathrm{L})$ from $R$. sativus and LMWH

\begin{tabular}{|l|c|c|c|}
\hline \multirow{2}{*}{ Conc. $(\mu \mathrm{l})$} & SOD (\% inhibition) & \multicolumn{2}{|c|}{ Cytotoxicity } \\
\cline { 2 - 4 } & Partial purified protein & Partial purified protein & LMWH \\
\hline $50 \mu \mathrm{L}$ & $69.4 \%$ & $70.6 \%$ & $51.5 \%$ \\
\hline $100 \mu \mathrm{L}$ & $89.8 \%$ & $85.0 \%$ & $67.2 \%$ \\
\hline $150 \mu \mathrm{L}$ & $96.2 \%$ & $98.8 \%$ & $79.0 \%$ \\
\hline $200 \mu \mathrm{L}$ & $98.0 \%$ & $99.1 \%$ & $86.8 \%$ \\
\hline Conc. $(\mu \mathrm{l})$ & SOD $(\%$ inhibition) & \multicolumn{2}{|c|}{ Cytotoxicity } \\
\hline & Partial purified protein & Partial purified protein & $\mathrm{LMWH}$ \\
\hline $50 \mu \mathrm{L}$ & $69.4 \%$ & $70.6 \%$ & $51.5 \%$ \\
\hline $100 \mu \mathrm{L}$ & $89.8 \%$ & $85.0 \%$ & $67.2 \%$ \\
\hline $150 \mu \mathrm{L}$ & $96.2 \%$ & $98.8 \%$ & $79.0 \%$ \\
\hline $200 \mu \mathrm{L}$ & $98.0 \%$ & $99.1 \%$ & $86.8 \%$ \\
\hline
\end{tabular}

Table 2: Total Lipids, DNA and RNA contents in liver tissues of mice of groups I VI

\begin{tabular}{|c|l|l|l|}
\hline $\begin{array}{l}\text { Parameters } \\
\text { Group }\end{array}$ & $\begin{array}{l}\text { Total lipid } \\
(\boldsymbol{\mu g} / \mathbf{g m} \text { tissue })\end{array}$ & $\begin{array}{l}\text { RNA } \\
(\boldsymbol{\mu g} / \mathbf{g m} \text { tissue })\end{array}$ & $\begin{array}{l}\text { DNA } \\
(\boldsymbol{\mu g} / \mathbf{g m} \text { tissue })\end{array}$ \\
\hline G I & $538.8 \pm 109.7$ & $119.1 \pm 11.7$ & $89.0 \pm 7.0$ \\
\hline G II & $601.4 \pm 142.6$ & $123.3 \pm 9.2$ & $92.7 \pm 7.5$ \\
\hline G III & $634.9 \pm 136.6$ & $116.7 \pm 10.2$ & $88.3 \pm 9.8$ \\
\hline G IV & $293.0 \pm 63.3 * *$ & $172.4 \pm 11.9 * *$ & $139.3 \pm 4.2^{* *}$ \\
\hline G VI & $586.1 \pm 214.2^{\text {aa }}$ & $136.2 \pm 9.3^{* \text { aa }}$ & $111.5 \pm 10.2^{* * \text { aa }}$ \\
\hline G VI & $491.1 \pm 72.8^{\text {aa }}$ & $141.1 \pm 7.3^{* * \text { aa }}$ & $121.0 \pm 11.2^{* *},{ }^{\text {aa }}$ \\
\hline
\end{tabular}

The results represented as $\mathrm{M} \pm \mathrm{SD} \quad$ Number of cases $=6$

$(*)$ Significant $(\mathrm{p}<0.05) \quad(* *)$ highly significant $(\mathrm{p}<0.005)$ compared to group GI

$\left({ }^{a}\right)$ Significant $(\mathrm{p}<0.05) \quad\left({ }^{\mathrm{a} a}\right)$ highly significant $(\mathrm{p}<0.005)$ compared to group GV

Group I: Normal mice saline-treated (control):

Group II: Normal mice-treated with the partial purified SOD:

Group III: Normal mice-treated with low molecular weight heparin (LMWH):

Group IV: EAC-bearing mice saline treated:

Group V: EAC-bearing mice treated with the purified SOD:

Group VI: EAC-bearing mice treated with low molecular weight heparin: 
Table 3: SOD activity and blood levels of GSH, nitric oxide, and MDA in RBCs of mice of groups I - VI

\begin{tabular}{|c|l|l|l|l|}
\hline $\begin{array}{l}\text { Parameters } \\
\text { Group }\end{array}$ & $\begin{array}{l}\text { MDA (Mole/ } \\
\text { ml. RBCs) }\end{array}$ & $\begin{array}{l}\text { Nitric oxide } \\
\boldsymbol{\mu m o l} / \mathbf{l} .\end{array}$ & $\begin{array}{l}\text { GSH (mmol./I } \\
\text { RBCs) } \times \mathbf{1 0 0 0}\end{array}$ & $\begin{array}{l}\text { SOD } \\
\text { (inhibition \%) }\end{array}$ \\
\hline G I & $4.38 \pm 1.256$ & $43.3 \pm 5.2$ & $2711.5 \pm 605.4$ & $39.2 \pm 11.8$ \\
\hline G II & $4.73 \pm 1.62$ & $41.2 \pm 6.1$ & $2624.1 \pm 765.3$ & $56.0 \pm 7.7 *$ \\
\hline G III & $5.58 \pm 0.71$ & $44.3 \pm 5.6$ & $2765.9 \pm 444.9$ & $49.3 \pm 5.3$ \\
\hline G IV & $7.99 \pm 1.17 * *$ & $91.3 \pm 5.0 * *$ & $1165.2 \pm 580.9 * *$ & $40.2 \pm 8.4$ \\
\hline G V & $5.56 \pm 1.24^{\mathrm{a}}$ & $65.0 \pm 7.5 * *$ aa & $2009.2 \pm 365.3 *$ a & $82.1 \pm 3.8 * *$ aa \\
\hline G VI & $5.40 \pm 1.47^{\mathrm{a}}$ & $71.5 \pm 6.9 * *$ aa & $2040.9 \pm 236.1 *$ a & $74.3 \pm 9.5 * *$ aa \\
\hline
\end{tabular}

The results represented as $\mathrm{M} \pm \mathrm{SD} \quad$ Number of cases $=6$

(*) Significant $(\mathrm{p}<0.05) \quad(* *)$ highly significant $(\mathrm{p}<0.005)$ compared to group GI

$\left({ }^{a}\right)$ Significant $(\mathrm{p}<0.05) \quad\left({ }^{a a}\right)$ highly significant $(\mathrm{p}<0.005)$ compared to group GV

Group I: Normal mice saline-treated (control):

Group II: Normal mice-treated with the partial purified SOD:

Group III: Normal mice-treated with low molecular weight heparin (LMWH):

Group IV: EAC-bearing mice saline treated:

Group V: EAC-bearing mice treated with the purified SOD:

Group VI: EAC-bearing mice treated with low molecular weight heparin:

Table 4: Total ascetic volume and serum levels of TGF- $\beta$ and VEGF in mice of groups I - VI

\begin{tabular}{|c|c|c|c|}
\hline $\begin{array}{l}\text { Parameters } \\
\text { Group }\end{array}$ & $\begin{array}{c}\text { Ascetic } \\
\text { volume (ml) }\end{array}$ & VEGF ( pg/ml ) & TGF- $\beta(\mathrm{pg} / \mathrm{ml})$ \\
\hline G I & ------------ & $122.2 \pm 24.7$ & $102.7 \pm 12.4$ \\
\hline G II & ------------ & $122.3 \pm 24.0$ & $115.6 \pm 21.5$ \\
\hline G III & ------------ & $127.5 \pm 31.3$ & $105.4 \pm 15.5$ \\
\hline G IV & $8.1 \pm 1.4$ & $720.2 \pm 26.4 * *$ & $568.6 \pm 28.8 * *$ \\
\hline G V & $0.8 \pm 0.7^{\text {aa }}$ & $273.7 \pm 65.6 * *$ aa & $233.0 \pm 44.9 * *$ aа \\
\hline G VI & $2.0 \pm 2.1^{\mathrm{aa}}$ & $337.6 \pm 60.9 * *$ aа & $296.4 \pm 49.7 * *$ aа \\
\hline
\end{tabular}

The results represented as $\mathrm{M} \pm \mathrm{SD} \quad$ Number of cases $=6$

(*) Significant $(\mathrm{p}<0.05) \quad(* *)$ highly significant $(\mathrm{p}<0.005)$ compared to group GI

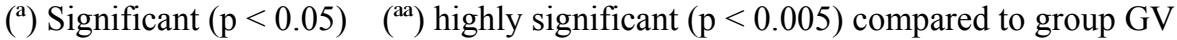

Group I: Normal mice saline-treated (control):

Group II: Normal mice-treated with the partial purified SOD:

Group III: Normal mice-treated with low molecular weight heparin (LMWH):

Group IV: EAC-bearing mice saline treated:

Group V: EAC-bearing mice treated with the purified SOD:

Group VI: EAC-bearing mice treated with low molecular weight heparin: 
Table 5: Serum levels of albumin and Serum activities of ALT, ALK-P and $\gamma$-GT in mice of groups I - VI

\begin{tabular}{|c|l|l|l|l|}
\hline $\begin{array}{l}\text { Parameters } \\
\text { Group }\end{array}$ & $\begin{array}{l}\text { ALK-P } \\
\text { (IU/l.) }\end{array}$ & $\boldsymbol{\gamma}$-GT (IU/ l.) & ALT (IU/l.) & Albumin ( g/dl ) \\
\hline G I & $61.8 \pm 11.1$ & $31.1 \pm 8.9$ & $29.3 \pm 4.3$ & $2.7 \pm 0.2$ \\
\hline G II & $63.3 \pm 9.4$ & $35.0 \pm 8.2$ & $27.8 \pm 4.4$ & $2.8 \pm 0.2$ \\
\hline G III & $58.9 \pm 6.4$ & $37.3 \pm 6.6$ & $25.7 \pm 3.6$ & $2.8 \pm 0.2$ \\
\hline G IV & $122.8 \pm 18.0^{* *}$ & $111.8 \pm 17.3^{* *}$ & $50.4 \pm 8.1^{* *}$ & $1.7 \pm 0.3^{* *}$ \\
\hline G V & $71.3 \pm 6.3^{\text {aa }}$ & $34.9 \pm 5.2^{\text {aa }}$ & $29.5 \pm 5.1^{\text {aa }}$ & $2.3 \pm 0.2^{* * \text { aa }}$ \\
\hline G VI & $83.0 \pm 12.4^{*},^{\text {aa }}$ & $51.3 \pm 23.5^{* a}$, & $34.1 \pm 5.6^{\text {aa }}$ & $2.2 \pm 0.2^{* * a}$ \\
\hline
\end{tabular}

The results represented as $\mathrm{M} \pm \mathrm{SD} \quad$ Number of cases $=6$

(*) Significant $(\mathrm{p}<0.05) \quad(* *)$ highly significant $(\mathrm{p}<0.005)$ compared to group GI

$\left({ }^{a}\right)$ Significant $(\mathrm{p}<0.05) \quad\left({ }^{\text {aa }}\right)$ highly significant $(\mathrm{p}<0.005)$ compared to group $\mathrm{GV}$

Group I: Normal mice saline-treated (control):

Group II: Normal mice-treated with the partial purified SOD:

Group III: Normal mice-treated with low molecular weight heparin (LMWH):

Group IV: EAC-bearing mice saline treated:

Group V: EAC-bearing mice treated with the purified SOD:

Group VI: EAC-bearing mice treated with low molecular weight heparin:

Table 6 Median survival time of treated and untreated EAC-bearing mice

\begin{tabular}{|l|l|l|}
\hline Group & Median survival time (Day) & Percentage increase of life span \\
\hline Tumor & $12.25 \pm 2.5$ & $\ldots \ldots \ldots$ \\
\hline Treated(SOD) & $19.00 \pm 4.69$ & $155.1 \%$ \\
\hline Treated(H) & $15.75 \pm 4.11$ & $128.5 \%$ \\
\hline
\end{tabular}

Values are expressed as mean \pm SD $(n=4)$

Table 7: Correlations between the different parameters of mice of groups I - VI

\begin{tabular}{|l|l|l|l|l|l|l|l|}
\hline Parameters & GSH & SGPT & $\boldsymbol{\gamma}$-GT & Alb & $\begin{array}{l}\text { Tumor } \\
\text { volume }\end{array}$ & $\begin{array}{l}\text { Total } \\
\text { lipid }\end{array}$ & NO \\
\hline $\begin{array}{l}\text { DNA } \\
(\mu \mathrm{g} / \mathrm{g} \text {. tissue) }\end{array}$ & $\begin{array}{l}\mathrm{r}=-0.63 \\
\mathrm{p}<0.0001\end{array}$ & $\begin{array}{l}\mathrm{r}=0.9 \\
\mathrm{p}<0.0001\end{array}$ & $\begin{array}{l}\mathrm{r}=0.72 \\
\mathrm{p}<0.0001\end{array}$ & $\begin{array}{l}\mathrm{r}=-0.81 \\
\mathrm{p}<0.0001\end{array}$ & $\begin{array}{l}\mathrm{r}=0.77 \\
\mathrm{p}<0.0001\end{array}$ & $\begin{array}{l}\mathrm{r}=-0.55 \\
\mathrm{p}<0.0001\end{array}$ & $\begin{array}{l}\mathrm{r}=0.88 \\
\mathrm{p}<0.0001\end{array}$ \\
\hline $\begin{array}{l}\text { MDA } \\
\text { (Mole/1ml }\end{array}$ & $\mathrm{r}=-0.30$ & $\mathrm{r}=0.58$ & $\mathrm{r}=0.65$ & $\mathrm{r}=-0.51$ & $\mathrm{r}=0.61$ & $\mathrm{Ns}$ & $\mathrm{r}=0.54$ \\
$\mathrm{RBCs})$ & $\mathrm{p}<0.05$ & $\mathrm{p}=0.0001$ & $\mathrm{p}<0.0001$ & $\mathrm{p}<0.001$ & $\mathrm{p}<0.05$ & & $\mathrm{p}<0.001$ \\
\hline $\begin{array}{l}\text { VEGF } \\
(\mathrm{pg} / \mathrm{ml})\end{array}$ & $\mathrm{r}=-0.69$ & $\mathrm{r}=0.84$ & $\mathrm{r}=0.88$ & $\mathrm{r}=-0.82$ & $\mathrm{r}=0.93$ & $\mathrm{r}=-0.52$ & $\mathrm{r}=0.91$ \\
\hline $\begin{array}{l}\text { Albumin } \\
(\mathrm{g} / \mathrm{dl})\end{array}$ & $\mathrm{r}=0.0001$ & $\mathrm{p}<0.0001$ & $\mathrm{p}<0.0001$ & $\mathrm{p}<0.0001$ & $\mathrm{p}<0.0001$ & $\mathrm{p}<0.0001$ & $\mathrm{p}<0.0001$ \\
\hline
\end{tabular}

(p) Probability, (r) correlation coefficient

Significant $(\mathrm{P} \leq 0.05)$, highly significant $(\mathrm{p} \leq 0.001)$

Correlation is considered weak at $r=0.50$, moderate at $r=0.50-0.75$ and strong at $r$

$=0.80-1.00$ 


\section{DISCUSSION}

The present work aimed to study the potent effects of SOD-like activity protein partial purified from $R$. Sativus roots and low molecular weight heparin (fraxiparine) on TGF- $\beta$ and VEGF in EAC-bearing mice. The Ehrlich tumor was initially described as spontaneous murine mammary adenocarcinoma. It is a rapidly growing carcinoma with very aggressive behavior and is able to grow in most strains of mice. In ascetic form, it has been used as transplantable tumor model to investigate the antitumor effect of several substances ${ }^{[37]}$.

In the present study, the partial purified protein showed high SODlike activities (about 98\%) as shown in (Table 1). Such results confirm the tendency of such protein to consume $\mathrm{O}_{2}{ }^{\circ}$ radical produced during photosensitization and act as free radical scavengers. Ben Salah-Abbès reported that, the extract of radish contains many antioxidant compounds that protect against the toxicity resulting from mycotoxin (Zearalenone) ${ }^{[38]}$. In addition, the invitro cytotoxic activity of natural protein and heparin against EAC cell lines explains its significant antitumor activity against ascites as shown in (Table 1).

In contrast, the levels of total lipids in liver tissues of groups $\mathrm{V}$ and VI showed high elevation after treatment as shown in Table 2, which confirms the suggestion that these materials prevent tumor growth and metastases.

The present study showed higher levels of RNA and DNA and total volume of ascetic fluid in EACbearing mice compared to the corresponding controls. These elevations was accompanied by a decrease in levels of total lipids compared to the control (Table 2), confirming the existence of a catabolic state accompanying the growth of the tumor cells ${ }^{[39 !}$. This increase in DNA and RNA levels and high replication of the tumor cells needs high energy; so tumor cell growth is usually consuming the energy sources including lipids and proteins. These explanations are confirmed by the established negative correlation between DNA and both total lipids and albumin (Table 7). Habib et al., reported that, the tumor cell growth requires high energy, therefore the catabolic effect of the tumor cell negatively correlated with the total lipids in liver tissues of the tumorized mice ${ }^{[14]}$. After treatment with the partially purified protein, these parameters restored their normal levels (groups V and VI) by inhibiting the tumor DNA synthesis ${ }^{[40]}$. These results agree with the results of Esmat [41]. In EAC-bearing hosts, regular rapid increase in ascetic fluid volume was observed. The ascetic fluid is the direct nutritional source for tumor cells, and the faster increase in ascites fluid with tumor growth could possibly be a mean to meet the nutritional requirements of tumor cells ${ }^{[42]}$. The results of the present study confirm the previous finding in that the rate of the tumor growth was significantly inhibited in the tumorized mice after treatment with the natural extract and heparin as shown in Table 2. 
Glutathione, a potent inhibitor of neoplastic process, plays an important role as an endogenous antioxidant system that is found particularly in high concentration in liver and is known to have key function in the protective process ${ }^{[43]}$. In the present study, the mean levels of GSH were significantly elevated in EAC-bearing mice treated with the natural SODlike activity protein and heparin compared to those of EAC-bearing untreated mice $(\mathrm{P}<0.05)$, indicating that the used material can be implicated in the redox cycle involved in GSH production ${ }^{[44]}$. Reduced glutathione is central to the cellular antioxidant defenses and acts as an important cofactor for antioxidant enzymes ${ }^{[45]}$.

MDA, the end product of lipid peroxidation was reported to be higher in carcinomatous tissue than that in the non diseased organs. The level of MDA reflects the extent of membrane lipid peroxidation and hence cell membrane damage and correlated with advanced clinical stages and the impairment is related to tumor progression. Moreover, it has been claimed that MDA acts as a tumor promoter and co-carcinogenic agent because of its high cytotoxicity and inhibitory action on protective enzymes. Low levels of MDA indicate inhibition of lipid peroxidation. The biochemical determination of MDA serves to indicate lipid peroxide formation. Zhang et al., reported that, LMWH could significantly decrease MDA content and increase SOD activity in ischemic brain ${ }^{[46]}$. It is clear from this study that $R$. Sativa inhibits lipid peroxidation and provides protection by strengthening the antioxidants effect by glutathione [47]

One mechanism that macrophages use to exert their cytostatic and cytolytic effects on the target tumors is by the release of NO by the activation of the cytosolic, NADPH-dependent enzyme inducible NO synthase (iNOS) ${ }^{[48]}$ In the present study, EAC-bearing mice showed a highly significant elevation in NO level compared to normal mice. In contrast, EAC-bearing mice treated with the natural SOD-like activity protein and LMWH showed a highly significant reduction in NO level compared to EAC-bearing untreated mice. Such results confirm the tendency of the natural purified protein and LMWH to reduce the cytotoxicity effect of EAC cells. In the present study, EAC-bearing mice treated with natural SOD-like activity protein showed an increase of $155.1 \%$ in their life span and those treated with the low molecular weight heparin showed an increase of $128.5 \%$ compared to the tumorized untreated mice (Table 6).

All of the interactions between the hemostatic system and tumor cells are involved in the promotion of angiogenesis ${ }^{[49]}$. Furthermore, several of the steps in the development of angiogenesis can be suppressed by unfractionated heparin, (UFH) LMWH, and nonanticoagulant molecules ${ }^{[50]}$. The complex interactions of these various mechanisms were recently reviewed by Ruf ${ }^{[51]}$. Thus, prominent roles in angiogenesis involve the release of growth factors such as VEGF ${ }^{\text {[51] }}$.

The suppression of angiogenesis has been promoted as one of the 
mechanisms whereby anticoagulants such as UFH and LMWH may suppress tumor growth and metastasis. In experimental models assessing endothelial capillary tube formation and cell proliferation in cultures have shown that UFH and various LMWHs can suppress angiogenesis, although not all to the same extent ${ }^{[52]}$. Ratner reported an association of thrombosis with the anti-angiogenic therapy which further highlights the complex interaction of angiogenesis with the hemostatic system ${ }^{[53]}$.

Ghosh et al., indicated that tumor volume and its growth rate increase with increasing angiogenesis and VEGF level of the host and the rate of VEGF secretion is positively correlated well with tumor volume ${ }^{[54]}$. The present results agree with these observations. After treatment, the tumorized mice which were treated with the partial purified protein with SOD like activity and LMWH (groups $\mathrm{V}$ and VI), VEGF levels showed a highly significant decrease compared to that of the tumorized untreated mice, The latter result confirms the anti-angiogenic properties of the LMWH in addition to their antithrombotic properties. This is because short heparin fragments have been shown to inhibit the binding of VEGF to its receptors on endothelial cells ${ }^{[55]}$.

TGF- $\beta$, is a multifunctional cytokine that regulates cell proliferation, differentiation and extracellular matrix production ${ }^{[56]}$. Also, TGF- $\beta$ may contribute to tumor pathogenesis by direct support of tumor growth and influence on local microenvironment, resulting in immunosuppression for all cells of the immune system, induction of angiogenesis, and modification of the extracellular matrix ${ }^{[57]}$. VozeninBrotons et al., reported that, SOD could significantly reduce TGF- $\beta 1$ expression, thus demonstrating that SOD might be proposed as a potent antagonist of that major fibrogenic growth factor ${ }^{[58]}$. In the present study, TGF- $\beta$ was highly significantly elevated in EAC-bearing mice compared to normal mice (Table 4). However, after treatment as in groups $\mathrm{V}$ and VI, TGF- $\beta$ level was highly significantly decreased compared to that of the tumorized untreated mice. These results confirm the abilities of the LMWH and the natural SOD-like activity protein to down-regulate the level of TGF- $\beta$ and reduce the growth and metastasis of EAC cells.

In the present results, the activities of ALT, ALP and $\gamma$-GT were highly increased in the sera of the untreated EAC-bearing mice and the level of albumin was decreased (Table 5). The reduction in the activities of both $\gamma$-GT and ALT after treatment with both natural SOD-like activity protein and LMWH compared with those of the tumorized untreated mice can confirms the anti-tumor effect of the two materials. Similar to that, reduction of the activities of the all elevated enzymes $(\mathrm{P}<0.05)$ to near normal levels in animals treated with both Jasminum sambac and 5 'fluorouracil were observe ${ }^{[59]}$.

Natural SOD-like activity protein is economical and of low toxicity and this is perhaps the advantage over synthetic agents which exhibit normal tissue toxicity. 


\section{CONCLUSION}

From the above observations one can conclude that, the naturally and the partially purified protein from $R$. sativus roots with SOD-like activity and the LMWH (fraxiparine) can be used to inhibits EAC cell growth possibly by many mechanisms including their antioxidative and antiangiogenic effects.

\section{REFERENCES}

1. Keating, D. J. (2008): Mitochondrial dysfunction, oxidative stress, regulation of exocytosis and their relevance to neurodegenerative diseases. J. Neurochem, 104(2): 298-305.

2. Valko, M., Rhodes, C. J., Moncol, J., Izakovic, M. and Mazur, M. (2006): Free radicals, metals and antioxidants in oxidative stress-induced cancer. Chem. Biol. Interact., 160(1): 140.

3. Fukui K, Takatsu H, Koike T and Urano $S$ (2010): Hydrogen peroxide induces neurite degeneration: Prevention by tocotrienols. Free Radic. Res., 45(6): 681-691.

4. Sato $Y$, Itagaki S, Oikawa S, Ogura J, Kobayashi M, Hirano $T$, Sugawara $M$ and Iseki $K$ (2011): Protective effect of soy isoflavone genistein on ischemiareperfusion in the rat small intestine. Bio. Pharm. Bull., 34(9): 1448-1454.

5. Cam Y, Atasever A, Eraslan G, Kibar M, Atalaym O, Beyazm L, Incim $A$ and Liman BC (2008): Eimeria stiedae: experimental infection in rabbits and the effect of treatment with toltrazuril and ivermectin. Exp. Parasitol., 119(1): 164-172.

6. Valko M, Leibfritz D, Moncol $J$, Cronin MT, Mazur $M$ and Telser J (2007): Free radicals and antioxidants in normal physiological functions and human disease. Int. J. Biochem. Cell Biol., 39(1): 44-84.

7. Miller AF (2004): Superoxide dismutases: active sites that save, but a protein that kills, Curr. Opin. Chem. Biol., 8(2): 162168.

8. Cooke MS, Evans MD, Dizdaroglu $M$ and Lunec $J$ (2003): Oxidative DNA damage: mechanisms, mutation, and disease, FASEB J., 17(10): 11951214.

9. Rahman NA, Mori K, Mizukami M, Suzuki T, Takahashi $\mathbf{N}$ and Ohyama $\mathbf{C}$ (2009): Role of peroxynitrite and recombinant human manganese superoxide dismutase in reducing ischemia-reperfusion renal tissue injury, Transplant. Proc., 41(9+): 3603-3610.

10. Sfaxi IH, Ferraro D, Fasano E, Pani G, Limam $F$ and Marzouki MN (2009): Inhibitory effects of a manganese superoxide dismutase isolated from garlic (Allium sativum L.) on in vitro tumoral cell growth, Biotechnol. Prog., 25(1): 257264.

11. Feng W, Mei S, Wenjie $Y$ and Luyuan H (2011): High-level soluble expression of recombinant human manganese superoxide dismutase in 
Escherichia coli, and its effects on proliferation of the leukemia cell. Protein Expr. Purif.., 77(1): 46-52.

12. Chaturvedi $P$ and Akala $H$ (2001): Effect of Raphanus sativus root extracts on glucose level in normal and diabetic rats. J. Appl. Zool. Res., 12: 172-177.

13. Sipos P, Hagymasi K, Lugasi A, Feher E. and Blazovics $A$ (2002): Effect of black radish root ( $R$. sativus $L$ var niger) on the colon mucosa in rats fed a fat rich diet. Phytother Res., 16(7): 677-9.

14. Habib SA and Othman EA (2012): In vitro upregulation of erythrocytes glucose uptake by Raphnus sativa extract in diabetic patients. Biochimie 94(5):1208 12.

15. Salah-Abbès JB, Abbès $S$, Ouanes Z, Houas Z, AbdelWahhab MA, Bacha $H$ and Oueslati R (2008): Tunisian radish extract (Raphanus sativus) enhances the antioxidant status and protects against oxidative stress induced by zearalenone in Balb/c mice. J. Appl. Toxicol., 28(1), $6-14$.

16. Falanga $A$ and Marchetti $M$ (2007): Heparin in tumor progression and metastatic dissemination. Semin. Thromb. Hemost., 33(7): 688-694.

17. Zacharski LR, and Lee AY (2008): Heparin as an anticancer therapeutic. Expert. Opin. Investig. Drugs 17(7) 1029-37.

18. Niers TM, Klerk CP, DiNisio M, Van Noorden CJ, Büller HR, Reitsma PH, Richel DJ. (2007): Mechanisms of heparin induced anti-cancer activity in experimental cancer models. Crit. Rev. Oncol. Hematol., 61(3) 195207.

19. Simka $M$ and Urbanek $T$ (2009): Anti-Metastatic Activities of Heparins. J. Cancer Mol., 5(1): 3-8.

20. Icli F, Akbulut H, Utkan G, Yalcin B, Dincol D, Isikdogan A, Demirkazik A, Onur H, Cay F and Buyukcelik A (2007): Low molecular weight heparin (LMWH) increases the efficacy of cisplatinum plus gemcitabine combination in advanced pancreatic cancer. J. Surg. Oncol., 95(6), 507-512.

21. Lowry OH, Rosenbrough MY, Farr AL. and Randall RJ (1951): Protein measurement with the Folin phenol reagent, J. Biol. Chem., 193(1) 265-275.

22. DeChatelet L, McCall C, McPhail $L$ and Johnston $R$ (1974): Spectrophotometric method for determination of superoxide dismutase enzyme in serum, J. Clin. Invest., 53(4): 1197.

23. Laemmli, U. K. (1970): Cleavage of structural proteins during the assembly of the head of bacteriophage T4. Nature 227(5259): 680-685.

24. Maclimans, W. F., Davis, E. V., Glover, F. L. and Rake, G. W. (1957): The submerged culture of mammalian cells: the spinner culture. J. Immunol., 79(5):428433.

25. Gupta, M., Mazumder, U. K., Kumar, R. S. and Kumar, T. S. (2004): Antitumor activity and antioxidant role of Bauhinia 
racemosa against Ehrlich ascites carcinoma in Swiss albino mice. Acta. Pharmacol. Sin., 25(8): 1070-1076.

26. Schneider, W. C. (1945): Phosphorous compounds in animal tissues I. Extraction and estimation of deoxypentose nucleic acid and of pentose nucleic acid. J. Biol. Chem., 161: (293 - 303).

27. Dische, Z. and Schwatez, $K$. (1937): Microchemical method for the determination of different pentoses in the presence of other pentoses and hexoses. Mikrochim. Acta 2: 13- 18.

28. Mejbaum, W. (1939): Estimation of small amounts of pentose especially in derivatives of adenylic acid. J. Physiol. Chem., 258: 117- 120

29. Knight, J. A., Anderson, S. and Rawle, J. M. (1972): Chemical basis of the sulfophosphovanillin reaction for estimating total serum lipids. Clin. Chem., 18(3): 199-202.

30. Reitman, A. and Frankel, S. (1957): A colorimetric method for the determination of serum glutamic oxalacetic and glutamic pyruvic transaminases. Am. J. Clin. Path., 28(1):, 56-63.

31. El-Aaser, A. A. and ELMerzabani, M. M. (1975): Simultaneous determination of 5 . - nucleotidases and alkaline phosphatase. Z. Klin. Chem. Klin. Biochem., 13(10): 453 - 459.

32. Persijn, JP, Van-der Slike, W. (1976): A new method for the determination of $\gamma$-glutamyl transferase in serum. J. Clin.
Chem. Clin. Biochem., 14(9): 421-427

33. Berkels, R., Purol-Schnabel, S. and Roesen, R. (2004): Measurement of nitric oxide by reconversion of nitrate/nitrite to NO. Methods Mol Biol.,, 279:1-8.

34. Doumas, B. T. (1971): Albumin standards and the measurement of serum albumin with bromcresol green. Clin. Chim. Acta 31(1) 8796.

35. Satoh K. (1978): Serum lipid peroxide in cerebrovascular disorders determined by a new colorimetric method. Clin Chim Acta 90(1):37-43.

36. Beutler, E., Duron, O. and Kelly, M. B. (1963): Improved method for the determination of blood glutathione. J. Lab. Clin. Med., 61: 882 - 8.

37. Segura, J. A., Ruiz-Bellido, M. A., Arenas, M., Lobo, C., Marquez, J. and Alonso, F.J. (2001): Ehrlich ascites tumor cells expressing anti-sense glutaminase RNA lose their capacity to evade the mouse immune system. Int. J. Cancer 91(3): 379-384.

38. Ben Salah-Abbès, J., Abbès, S., Abdel-Wahhab, M. A. and Oueslat, R. (2009): Raphanus sativus extract protects against Zearalenone induced reproductive toxicity, oxidative stress and mutagenic alterations in male Balb/c mice. Toxicon. 53 (5): 525-533.

39. Korekane, H., Nishikawa, A. and Imamura, K. (2003): Mechanisms mediating metabolic abnormalities in the livers of Ehrlich ascites tumor-bearing 
mice. Arch. Biochem. Biophys., 412(2): 216-22.

40. Crespy, V. and Williamson, G. (2004): A review of the health effects of green tea catechins in vivo animal model. .J. Nut., 134(12 Suppl., ): 3431S-3440S.

41. Esmat, A. Y. E. (1990): Studies of the effect of a Naturally Occurring Compound on some Biochemical Markers for Cancer in Mice, $\mathrm{PhD}$ Thesis. Biochemistry Dept., Faculty of Science, Ain Shames University, Egypt.

42. Dahanukar, S. A.; Kulkarni, R. A. and Rege, N. N. (2000): Pharmacology of medicinal plants and natural products. Indian $\mathrm{J}$. Pharmacol., 32: S81-S118.

43. Kathiriya, A., Das, K., Kumar, E. P. and Mathai, K. B. (2010): Evaluation of antitumor and antioxidant activity of oxalis Corniculata Linn. Against Ehrlich ascites carcinoma on mice. Iran. J. Cancer Prev., 3(4): 157 - 165..

44. Dougan, S. J., Habtemariam, A., McHale, S. E., Parsons, S. and Sadler, P. J. (2008): Catalytic organometallic anticancer complexes. Proc. Natl. Acad. Sci. (USA). 105 (33): 11628-11633.

45. Hayes, J. D., Flangan, J. U. and Jowsey, I. R. (2005): Glutathione transferases, Annu. Rev Pharmac. Toxicol., 45: 51-88.

46. Zhang ZG, Zhang QZ, Cheng YN, Ji SL, Du GH. (2007): Antagonistic effects of ultra-lowmolecular-weight heparin against cerebral ischemia/reperfusion injury in rats. Pharmacol. Res., 56:350-355.
47. Chaturvedi, P. (2008): Inhibitory Response of Raphanus sativus on Lipid Peroxidation in Albino Rats. Evid. Based Complement Alternat. Med., 5(1): 55-9.

48. Bredt, D. S. (1999): Endogenous nitric oxide synthesis: Biological functions and pathophysiology. Free Radic. Res., 31(6): 577-596.

49. Hostettler, N., Naggi, A., Torri, G., Ishai-Michaeli, R., Casu, B., Vlodavsky, I. and Borsig, L. (2007): P-selectin and heparanase-dependent antimetastatic activity of nonanticoagulant heparins. FASEB. 21(13): 3562-72.

50. Lee DY, Kim SK, Kim YS, Son DH, Nam JH, Kim IS, Park RW, Kim SY, Byun Y. (2007): Suppression of angiogenesis and tumor growth by orally active deoxycholic acid-heparin conjugate. Control Release. 118(3): 310-317.

51. Ruf, W., Khorana A. A. and Francis C. W. (2008): Ruf W: Hemostasis and angiogenesis. In: Khorana AA, Francis CW, editors. Cancer-Associated Thrombosis: New Findings in Translational Science, Prevention, and Treatment. New York: Informa Healthcare; 2007. p. 17-34.

52. Marchetti M, Vignoli A, Russo L, Balducci D, Pagnoncelli M, Barbui T, Falanga A. (2008): Endothelial capillary tube formation and cell proliferation induced by tumor cells are affected by low molecular weight heparins and unfractionated 
heparin. Thromb. Res., 121(5):637-645.

53. Ratner, M. (2004): Genentech discloses safety concerns over Avastin. Nat. Biotechnol., 22(10):1198.

54. Ghosh, S., Roy, S., Banerjee, $M$. and Maity, P. (2004): Modulation of Tumor Induced Angiogenesis in Ehrlich Ascites Tumor. J. Exp. Clin. Cancer Res., 23(4): 681-690.

55. Castelli, R., Porro, F. and Tarsia, P. (2004): The heparins and cancer: review of clinical trials and biological properties. Vasc. Med., 9(3): 205-213.

56. Jennings, M. T. and Pietenpol, J. A. (1998): The role of transforming growth factor $\beta$ in glioma progression. J. Neurooncol., 36(2): 123-140.

57. Kaklamani, V. G., Hou, N., Bian, Y., Reich, J., Offit, K., Michel, L.S., Rubinstein, W.S.,
Rademaker, A. and Pasche, $B$. (2003): TGF $\beta R 1 * 6 A$ and cancer risk: a meta-analysis of seven case-control studies. J. Clin. Oncol., 21(17): 3236-3243.

58. Vozenin-Brotons MC, Sivan V, Gault N, Renard C, Geffrotin C, Delanian S, Lefaix JL, Martin M. (2001): Anti-fibrotic action of $\mathrm{Cu} / \mathrm{Zn}$ SOD is mediated by TGF-beta 1 repression and phenotypic reversion of myofibroblasts. Free Radic. Biol. Med., 30(1): 30-42.

59. Kalaiselvi, M., Narmadha, R., Ragavendran, P., Ravikumar, G., Gomathi, D., Sophia, D., Raj, C.A., Uma, C. and Kalaivani, K. (2011): In vivo and in vitro antitumor activity of jasminum sambac (linn) alt oleaceae flower against daltons ascites lymphoma induced Swiss albino mice. Int. J. Pharm. and Pharmaceut. Sci,, 4(4): 144-147. 


\section{التاثير الفعال لبروتين له نشاط مشابه للسوبر اكسيد الايسميوتيز المستخلص

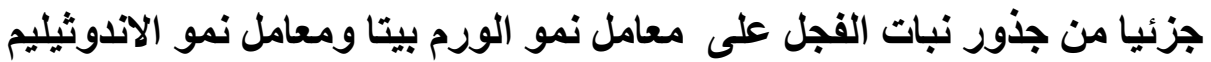 الوعائي فى الفئران المصابة بخلايا ايرلش السرطانية

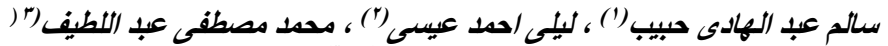

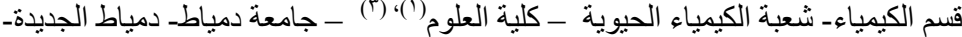

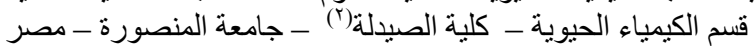

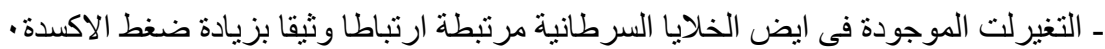

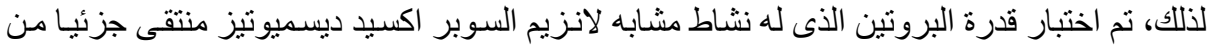

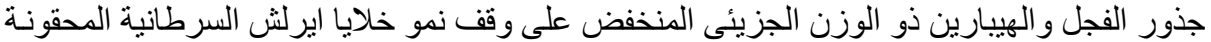

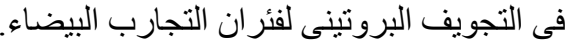

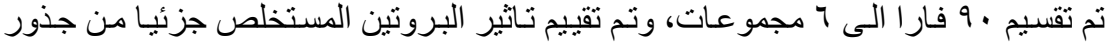

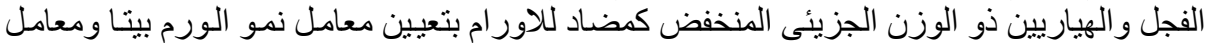

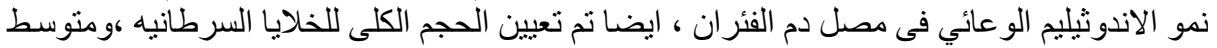

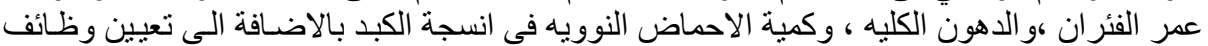

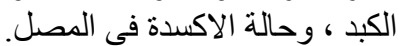

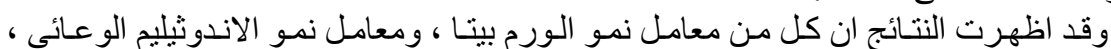

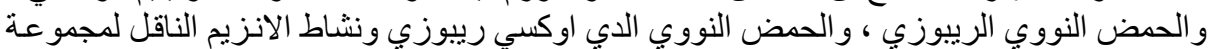

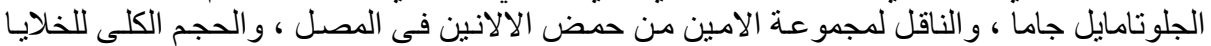

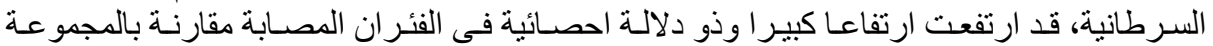

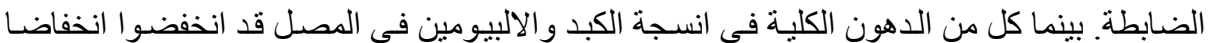

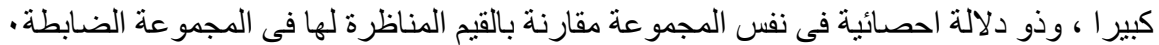

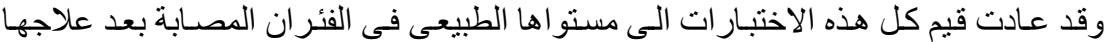

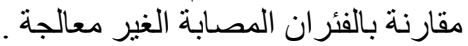

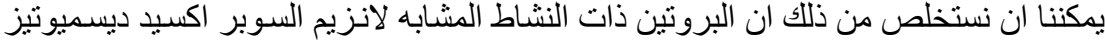

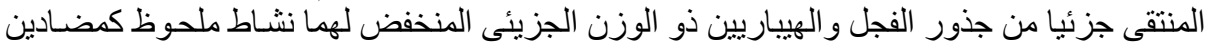

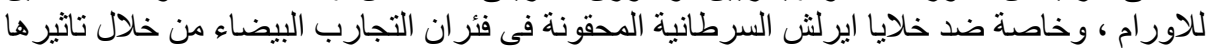

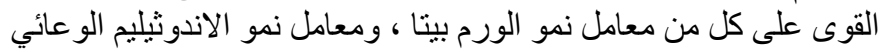

